\title{
Substance Abuse among In-School and Out-Of-School Youth in Sokoto, Northwestern Nigeria
}

\author{
${ }^{1}$ SARKINGOBIR, Y; ${ }^{2}$ DIKKO, $M$ \\ ${ }^{*}$ Department of Biology, Shehu Shagari College of Education Sokoto, Sokoto state, Nigeria \\ ${ }^{2}$ Department of Pharmacy, Sultan Abdurrahman College of Health Technology Gwadabawa, Sokoto state, Nigeria \\ *Corresponding Author Email: superoxidedismutase594@gmail.com; dikko.malami@gmail.com; Tel:09096266980
}

\begin{abstract}
The objective of this study was to investigate substance abuse amongst in-school and out-of-school youth in Sokoto, northwestern Nigeria using cross-sectional descriptive survey. In the course of the survey, the commonly use substances, causes, effects, and protection were assessed. The data obtained show that, most of the respondents were males (93\%), only few were females (6.7\%). All the respondents were Muslims. Most of the out-of-school youth (OSY) were married (80\%) and only $6.7 \%$ are married among in-school youth (ISY).The respondent's age was within 18-22 years in most cases. Most ( $80 \%$ ) of ISY were at senior secondary classes, $46.7 \%$ of OSY left school after primary education, $26.7 \%$ never attended school. Most of the respondents have more than 2 kids $(93.3 \%)$, only $6.7 \%$ have about 10 kids. Commonly cited drugs are: cigarette, cannabis, alcohol, inhalants, tranquilizers, opiates, and hallucinogens. Reasons for substance abuse were: social/ peer pressure, rebellion, overwork/learning, shyness, fear, parental influence, fun and lack of role model. It also revealed that ISY started drug use earlier than the OSY. Friends, drug pushers, curiosity introduced youth to drugs. Effects of substance abuse are: bad temper, disturbed sleep, ill-health, depression, anxiety, tiredness, disrespect, failure at workplace/school on individual. At family level the effects include: disgrace, breakdown of relationship, loss of confidence in child, and ill-health. While at friend's level, the effects include: breakdown of relationship, fear, anxiety. And at community or society levels, the effects listed were: crime, reduced productivity, violence, ill-health, high cost of treatment, accidents. To protect youth from substance abuse diverse efforts by government and NGOs and interventions are required.
\end{abstract}

DOI: $\underline{\text { https://dx.doi.org/10.4314/jasem.v24i9.10 }}$

Copyright: Copyright $(C) 2020$ Sarkingobir and Dikko. This is an open access article distributed under the Creative Commons Attribution License (CCL), which permits unrestricted use, distribution, and reproduction in any medium, provided the original work is properly cited.

Dates: Received: 25 August 2020; Revised: 25 September 2020; Accepted: 20 September 2020

Keywords: Substance abuse, drug, out-of-school youth, in-school youth, key informants, public health

Generally, drugs are helpful when they are properly used and destructive when they are misused or abused, but the abuse of substances or drugs has traverse the youth in large extent across the globe. Substance abuse is a harmful pattern of use of any substance (drug) for mood altering purposes, subsequently leading to frequent and serious problems. These problems can affect performance at school, work or home. In many instances, relationships with friends, parents, and households fade because of substance abuse (Nasiru et al., 2019a). Substance abuse can also be dubbed as the harmful or hazardous use of substances, including alcohol and other illicit drugs. Drug substances use can lead to dependence syndrome, a cluster of behavioural, cognitive, and physiological phenomena that develops after repeated substance use and that typically includes a strong desire to take the drug, difficulties in controlling its use, persistence in its use despite harmful consequences (Lawal and Aliyu, 2020). All the organs of the body are prone to damages due Substance abuse. The respiratory, digestive, heart, liver and nervous diseases have particularly been established to be due to the abuse of substances (Shekarchizadeh, 2013; Abubakar and Nasiru, 2019).
An estimated quarter of a billion people, or around 5 percent of the global adult population, use drugs at least once, more worrisome is the fact that about 29.5 million of those drug users, or 0.6 per cent of the global adult population, suffer from drug use problems leading to deaths and injuries. Substance abuse is a major universal health problem. It exposes the individuals to major socio-economic and health problems, and serves as a predisposing factor for crime in a society (Yusuf, 2013). Youth are very significant in any society. They are one of the greatest warewithal any nation can use to achieve development and economic growth. They remain the leaders of tomorrow. The youth are particular portion of the national population that is meant to be sensitive, energetic, and active and the most productive among the citizens. The youth are also most volatile and yet the most vulnerable segment of the population (Nasiru et al., 2019a). The worry is, no comprehensive data is available on the estimated number of use of drug substances in Nigeria or in Sokoto which was drawn from large and diverse actors (in-school youth, out-ofschool youth, key informants, sellers). Most of the studies are hospital- based and retrospective, making 
prediction of trends rather difficult and to curtail this problem there is need to understand the cause, effect and source of these drugs to individuals, family, and community (Fareo, 2012; Nasiru, 2015; Lawal and Aliyu, 2020). The objective of this study was to investigate substance abuse among in-school and outof-school youth in Sokoto, northwestern Nigeria, the commonly use substances, causes, effects, and protection.

\section{MATERIALS AND METHODS}

Research design: Cross-sectional descriptive survey was used to cover some selected schools and out of school groups, key informants and selling points in Sokoto.

Research setting:This research was carried out in Sokoto state, Nigeria. Nigeria as a nation in Africa lies between $50 \mathrm{~N}$ equator and 30 and 40 east of the green which meridian. Nigeria composed of 36 states, with federal capital territory Abuja. There are seven hundred and seventy four local government areas. Sokoto is one of the 36 states of the federal Republic of Nigeria, with a total population of $4,427,760$ based on 2006 census report. Sokoto is located in the northwest part of the country; it formed boarders with Kebbi, Zamfara, and Niger republic (Sarkingobir and Abbas, 2017; Sarkingobir, 2020ab).

Target population:Targeted population in this study was the youth who use substances in Sokoto state. The study was carried when they are calm. Selected key informants were interviewed using questionnaire and Sell outlets were visually inspected.

Inclusion criteria: Sokoto youth within the age range of 18-25 who uses substances were included. Key informants from teachers, health workers and relations were included.

Sample size:Quality of information is the main aim in qualitative studies that is why smaller sample sizes are used in contrast with quantitative studies. Most PhD studies used 20, 30, 40, 10, 25 sample sizes respectively.

The sample size in this study was 60 youth drawn (30 in school youth, and 30 out of school youth) from the three senatorial zones of the state. 10 key informants and 10 drug sellers were enrolled (MacDougall and Fudge, 2001; Hodge et al., 2011; Sarkingobir and Abbas, 2017).

Sampling technique:Purposive, snowballing, and convenience sampling were used in this study.
Data collection methods and tools and management:A questionnaire was used to collect data with the help of voluntary research assistants after a pilot study. The data was analyzed using content analysis.

\section{RESULTS AND DISCUSSION}

Demographics of the youth:(28) $93 \%$ of the respondents were male, 0nly $2(6.7 \%)$ were females. $26(43.33 \%)$ of the respondents were $18-21,22(36.7 \%)$ were $17-22$, whereas $2(3.3 \%)$ failed to indicate their age. Out-of-school respondents (OSR) had 24(80\%) are single, $12(40 \%)$ were leaving together, and $2(6.7 \%)$ were divorced. In-school respondents (ISR) 18 were single, 2 were married and 2 did not indicate their status. All 60 respondents were Muslims. ISR, there were $24(80 \%)$ in SS, 2in JSS (junior secondary school) 2 in primary, 2 not indicated. OSR, 14(46.7\%) were primary school leavers, 4(13. \%) left school at SSS (senior secondary school), 2 left school at JSS, $8(26.7 \%)$ never attended school. Commonly used drugs are cigarette, tranquilizers, cannabis, volatile inhalants, hallucinogens and opiates.

Reasons for substance use and how they get it:ISR, social/peer pressure (28), then rebellion (16), overwork/learning (14), parental influence was the least (2). OSR, social/ peer pressure (26), rebellion, parental influence, lack of role model in school/society, and for fun; scored (4). The least was shyness and fear. Most of OSR started drugs at 1318(26), few started at 19-21(4).ISR, mostly started at (20)10-15. Others at 16-20. ISR echoed that Drug use is practiced at home (22), school (14), or both.OSR indicated that it was practiced both at home or school (24), then home (6).

Who introduced youth to drugs? OSR said friends (38). ISR said drug pushers (22), then friends (16), and the least was curiosity.Oh how people relate with drug abusers and drug addicts, 32 OSY said they mostly had bad interaction with people. 6 of them felt they experience fair relationship. Whereas, 2 think they had very good relationship with people. From ISY, 24 experienced fair relations with people, 12 said people relates with them badly.

Whereas, 2 felt that people relate to them excellently. Among OSY, 32 respondents agreed that drug abuse is increasing, while, 6 OSY were of the view that drug abuse is not rising.

Moreover, 32 ISY agreed that drug abuse is not increasing, 8 were of the view that drug abuse is on the rise.To protect youth from substance abuse, the following submissions were made by the respondents: 
Table 1: Ways of convincing youths to drug abuse

\begin{tabular}{lll}
\hline & OSR & ISR \\
\hline Item & Frequency & Frequency \\
Make brilliant & 10 & 32 \\
Happier & 24 & 32 \\
Stronger & 0 & 2 \\
Work for long & 30 & 4 \\
Brave & 6 & 2 \\
Confidence & 26 & 2 \\
Boost appetite & 2 & 4 \\
\hline
\end{tabular}

Table 2: Effects of drug use on individuals/friends/ community

\begin{tabular}{|c|c|c|c|}
\hline \multicolumn{4}{|l|}{ Out-of-school youth } \\
\hline Individual(Frequency) & Family(frequency) & Friends & Community \\
\hline Bad temper (10) & Disgrace (12) & $\begin{array}{l}\text { Breakdown of } \\
\text { relationship (18) }\end{array}$ & Crime (12) \\
\hline Disturbed sleep (8) & $\begin{array}{l}\text { Breakdown of } \\
\text { relationship (10) }\end{array}$ & Anxiety/fear (2) & $\begin{array}{l}\text { Reduce } \\
\text { productivity (8) }\end{array}$ \\
\hline III-health (6) & $\begin{array}{l}\text { Loss of confidence } \\
\text { in child (4) }\end{array}$ & & Violence (6) \\
\hline Depression (2) & & & Ill health (4) \\
\hline Anxiety (2) & & & $\begin{array}{l}\text { High cost of } \\
\text { treatment (2) } \\
\text { Breakdown in } \\
\text { work (2) }\end{array}$ \\
\hline \multicolumn{4}{|l|}{ In-school youth } \\
\hline Disturbed sleep (22) & $\begin{array}{l}\text { Breakdown in } \\
\text { family relationship } \\
\text { (34) }\end{array}$ & Anxiety(26) & $\begin{array}{l}\text { Crime(34) } \\
\text { Violence(6) }\end{array}$ \\
\hline IIl health (10) & Disgrace (24) & $\begin{array}{l}\text { Breakdown in } \\
\text { relationship (8) }\end{array}$ & Accidents(2) \\
\hline Bad temper (10) & Ill health (6) & & $\begin{array}{l}\text { High cost of } \\
\text { treatment (2) }\end{array}$ \\
\hline Bad temper (8) & $\begin{array}{l}\text { Loss of confidence } \\
\text { in child (4) }\end{array}$ & & \\
\hline \multicolumn{4}{|l|}{ Anxiety/Fear(8) } \\
\hline Tiredness (4) & & & \\
\hline Depression (4) & & & \\
\hline Failure to do work/ school (4) & & & \\
\hline Disrespect (2) & & & \\
\hline
\end{tabular}

Table 3: Protection of youth from substance abuse

\begin{tabular}{lll}
\hline Out -of -school youth & \multicolumn{1}{c}{ In-school youth } \\
\hline $\begin{array}{l}\text { Parents shall not expose children to drug } \\
\text { abuse }\end{array}$ & 38 & 10 \\
$\begin{array}{l}\text { Parents should give youth knowledge and } \\
\text { confidence they needs to make decisions }\end{array}$ & 28 & 32 \\
$\begin{array}{l}\text { Peer group educators } \\
\text { National campaign }\end{array}$ & 26 & 4 \\
\hline \multicolumn{2}{c}{ Key informants interview } \\
\hline
\end{tabular}

Types of substances and their uses: Generally they explained that substance abuse as the act of taking any drug (substance) which modifies mentality without medical advice or behavior of taking intoxicating substances. Common substances asserted by them include: cough syrup, cannabis, cigarette, tea and tablets. Most of the key informants (KIs) said substance abuse is increasing as explained by shops and sell outlets along the streets. Only few of them believed that substance abuse is decreasing. KIs said youth buy substances from markets, home, garage, chemists and vendors. The youth called substances with names like medicine, stimulants, and materials.
To protect youth from substance abuse there is need for making them knowledgeable, organized, guided, counseled, and monitoring.

Causes of substance abuse among youth are: Bad friends, accessibility, lack of proper parental care, and lack of education. Prevention of substance abuse was suggested in: Policies by government- Banning of imports of substances, drug education in school; extensive campaign against drugs; proper parental care; substance abusers treatment through rehabilitation and counseling. 
Table 4: Effects of substances on as echoed by KIs

\begin{tabular}{lll}
\hline Individual & Family & Community \\
\hline Dark body & Stigmatization & Stigmatization \\
Mental problems & Lack of relationship & Suicides \\
Theft & Disgrace & Political thugs \\
Untidiness & Indiscipline & Rise in crime \\
Toxicity & & Academic problems \\
& & Rise in lack of sexual discipline \\
\hline
\end{tabular}

Observation of sale outlets:Observation of sale outlets indicated both males and females patronize their supplies. The buyers are mostly 18-25 years. Most of the transactions take place in the night and it is peak during rainy season. No security outbreak was observed around the premises of drug outlets. The method of buying is open, direct, through boys and money is used.

In this study most of the respondents are male (93\%), only few are females (6.7\%). This might be because the practice among females was accorded less attention (Bassi et al., 2017). All the respondents are Muslims. Religion should have deterred them. Most of the OSY are married $(80 \%)$ and only $6.7 \%$ are married among ISY. Normally, people who go to school tend to stay longer before getting married. The respondent's age was within 18-22 years in most cases. Most $(80 \%)$ of ISY were at senior secondary classes, $46.7 \%$ of OSY left school after primary education, $26.7 \%$ never attended school. Most of the respondents have more than 2 kids $(93.3 \%)$, only $6.7 \%$ have about 10 kids. Commonly cited drugs are: cigarette, cannabis, alcohol, inhalants, tranquilizers, opiates, and hallucinogens. Similar to the findings of Fareo (2012) Omage and Omage (2012), Nasiru et al (2019a). Therein, reasons for substance abuse were: social/ peer pressure, rebellion, overwork/learning, shyness, fear, parental influence, fun and lack of role model. It also revealed that ISY started drug use earlier than the OSY. Friends, drug pushers, curiosity introduced youth to drugs. These are similar to findings of Okoshikoya and Alli (2006), Yusuf (2013), Nasiru (2015), Nasiru et al (2019b), Nasiru and Musawa (2019). There are several effects of substance abuse on the individual, friends, and Community. At individual level there are: bad temper, disturbed sleep, ill-health, depression, anxiety, tiredness, disrespect, failure at workplace/school. At family level the effects include: disgrace, breakdown of relationship, loss of confidence in child, and ill-health. At friend's level, the effects include: breakdown of relationship, fear, anxiety. And at Community or society levels, the effects listed were: crime, reduced productivity, violence, ill-health, high cost of treatment, accidents. Similar effects were reported by Fareo (2012), Ahmed (2012), Yusuf (2013), Nasiru (2015), Tracy (2016), Nasiru et al., (2019). To protect youth from substance abuse the following measures were submitted by the respondents: parents should not expose children to drugs, parents should give them confidence and proper knowledge to make decisions, peer group educators should work, and there should be national campaign against drugs. Nasiru et al.,(2018) reported similar findings.

Key informants (KIs):KIs cited, cough syrup, cannabis, alcohol, cigarette, tea and tablets as commonly used drugs among youth. Most of the KIs encounter substance abusers among the youth populations of 10years. There is an increasing trend of substance abuse and substances are sourced from markets, garages, homes, chemists, and vendors. All the effects of substance abuse stated by youth were similar to those submitted by the KIs, they added mental problems, dark skin, accessibility, political thugs, stigmatization and lack of sexual discipline. They believed bad friends, accessibility, improper parental care, and illiteracy are the causes of substance abuse. They equally believed, organization, guidance and counseling, and education, government interventions, campaign and rehabilitation prevents drug abuse among youth.

Observation of sell outlets:Mostly, youth (18-25 years) patronize the observed sell outlets in Sokoto. The inhabitants were calm and peaceful during their transactions and it mostly occur in the night and it become peak during rainy seasons. From the above we see that drug abuse is all pervasive, it is found both in schooled and out of school youth. Similar to past reports in the literature (Abdulmalik et al., 2009, Cofie, 2010).

Generally, drugs are useful when they are properly used. So many studies and trials are carried out to establish their safety. Therein, they are attached with adverse reactions or effects, let alone when misuse or abuse. They are destructive when they are misused or abused, but most youth care not. World over, the use of drug or substances is a major public health problem characterized with effects on individuals, friends, families and the communities. The abusers use a diverse array of substances and the menace requires diverse approaches for curtailments (Nasiru, 2015; Dikko et al., 2020ab). 
Conclusion: Substance abuse in Sokoto is similar among in-school and out-of school youth. The practice is wide and mostly among males who consumed many drug substances. It is also associated with several effects on individuals, families, and communities.

\section{REFERENCES}

Abdulmalik, J; Omigbodun, O; Beida O; Adedokun, B. (2009) Psychoactive substance use among children in informal religious schools (Almajiris) in northern Nigeria. Mental Health, Religion and Culture, 12:6, 527-542.

Abubakar, FU; Nasiru MA (2019).Psychoactive Substances Abuse among Renting Motorcyclists in Nigeria: A Qualitative Study. IOSR J. Nurs. Heal. Sci., 8(6): 2320-1959.

Ahmed, A. M. (2012). Substance Abuse among Undergraduate Student of Usmanu Danfodiyo University, Sokoto. Sok. J. Soci. Sci., 2(1): 136147.

Bassi, AP; Idoko, L; Ogundeko, TO; Ramyil, MSC; Abisoye-Ogunniyan, A.; Ogboke, EA; Thilza, SA; Sule, UO; Ante, EB; Baba, AI; Chimbuoyim, IN (2017). Substance abuse and it's prevalence among secondary school adolescents in Kagoro, Kaduna state, Nigeria. Worl. J. Res. Rev. 5(1):1116.

Cofie CN; (2010). Prevalence Of Substance Use Among Junior High School Pupils Of The Dangme West District. A Dissertation Submitted to the University of Ghana, in partial fulfillment of the requirements for the award of Master Of Public Health Degree. University Of Ghana Http://Ugspace.Ug.Edu.Gh

Dikko, M; Bello, SO; Chika, A; Mungadi, IA; Sarkingobir, Y; Umar, AI (2020a). Effect of Tamsulosin Use on Plasma Insulin Status in Benign Prostatic Hyperplasia Patients in Sokoto, Nigeria. J. of Appl. Sci. Environ. Manage. 24(4):543-548.

Dikko M., Bello, SO., Chika, A., Mungadi, IA., Sarkingobir, Y., Aliyu A. (2020b). Determination of Oral Glucose Tolerance (OGT) of Benign Prostatic Hyperplasia Patients Treated with Tamsulosin in Sokoto State, Nigeria Niger. J. Pharma. Appl. Sci. Res. 9(2): 33-39.

Fareo, DO; (2012). Drug abuse among Nigerian adolescents: Strategies for counseling. The Intern. J. Socia. Sci. Res., 5(20):342-347.
Hodge, DR; Marsiglia, FF; Nieri, T (2011). Religion and Substance Use among Youths of Mexican Heritage: A Social Capital Perspective. Social Work Research, 35(3), 137-146.

Lawal, N; Aliyu, MA (2020). Assessment of Causes and Effects of Drugs and Substances Abuse among Youth: A Case Study of Katsina Metropolis (North West Nigeria).Intern. Neuro. Dis. J. 14(1): 1-9.

MacDougall, C; Fudge, E (2001). Planning and recruiting the sample for focus groups and indepth interviews. Quali. Heal. Res, 11, 117-126.

Nasiru, BS (2015). Perceptions Of Youth On Substance Abuse In Sokoto, Sokoto State, Nigeria A Dissertation Is Submitted To The University Of Ghana, Legon In Partial Fulfilment Of The Requirement For The Award Of Master Of Science Nursing Degree.

Nasiru, BS; Yakubu, L; Abdulrahman, SM; Auwal, M; Abdulrahman, S; Zulkifilu, M (2018). Youth perception on control measures in reducing substance abuse in Sokoto state, Nigeria. Intern. J. Nurs. Medi. Sci. 7(2):736-754.

Nasiru, BS; Musawa, TS; Hassan, HM; Ejembi, EA (2019a). Exploring the perceived factors that lead to substance abuse among youth in Northern Nigeria. J. Res. Contemp. Issue. Human Kine. Heal. Edu. 5(9):15-23.

Nasiru, BS; Lydia, A; Alexander, A; Maru, SA (2019b). The perception of youth on the effects of substance abuse in Sokoto Nigeria. Worl. J. Pharma. Medi. Res. 5(9):122-129.

Omage, IE; Omage, IM (2012). Illicit drugs use and dependency among teenagers and young adults in Oredo local government area, Benin City, Nigeria. Europ. Scient. J., 8(20):187-210.

Okoshikoya, K.; Alli, A (2006). Perception of Drug Abuse amongst Nigerian Undergraduates. Worl. J. Medi. Sci., 1(2), 133-139.

Sarkingobir Y; Abbas, SS (2017). Factors that contributes to noncompliance of youths to blood donation in Sokoto State. Intern. J. Med. Biosci. 1(1):1-17.

Sarkingobir, Y (2020a). The brief history of the $7^{\text {th }}$ Sarkingobir of Gwadabawa, Alhaji Muhamamdu 
Zayyanu MFR. Int. J. Education. Res. Studi. 2(1):01-06.

Sarkingobir, Y (2020b). The second Sarkin Rafin Illela, Alh Buhari Muhamamd Tukur. Sokoto, Nigeria: University Press Limited, Usmanu Danfodiyo University Sokoto.

Shekarchizadeh, H; Khami, MR; Mohebbi, SZ; Ektiari, H; Virtanen, JI (2013). Oral health of drug abusers: A review of health effects and care. Iran. J. Pub. Heal. 42(9):929-940.
Tracy, N (2014). Causes of Drug Addiction - What Causes Drug Addiction? Retrieved November 3, 2014 , from http://www.healthyplace.com/addictions/drugaddiction/causes-of-drug-addiction-what-causesdrug-addiction/.

Yusuf, FA (2013). Effects of Peer Modelling Technique in Reducing Substance Abuse among Undergraduates in Osun State, Nigeria. IFE PsychologIA,; 21(1): 194-205. 